of the specimen's attribution to Homo, the competing arguments, and What It All Might Mean.

But if abstruse anatomical arguments are not to your taste, Lucy's Child has something for everyone: there are florid descriptions of what it is like to be involved in a field season, vignettes of street life in Dar-es-Salaam and effusive penportraits of many of the scientists involved in the dig. The abundant flashbacks to critical moments in our understanding of human evolution framed by purplish descriptions of East African sunsets add to the impression of an uneventful amble to the drugstore made into a tenday hike across the Siberian tundra pursued by ravening hordes of mammoths. The story starts, even, with a situation comedy: Johansen stuck in the sweltering night of his hotel in Dar-es-Salaam, paradoxically freezing cold because of a badly

\section{The smallest continent}

\section{Jared Diamond}

Mammals of New Guinea. By Timothy Flannery. The Australian Museum (Robert Brown and Associates): 1990. Pp. 440. A\$79.95.

The Birds of Papua New Guinea. By Brian J. Coates. Dove Publications (Box 59, Alderly, Queensland 4051, Australia). Volume 1 (Nonpasserines): 1985. Pp. 464. US $\$ 85, A \$ 110$, £60. Volume II (Passerines): 1990. Pp. 576. US \$110, $A \$ 140, £ 70$.

Australia is famous for having the world's most distinctive mammal fauna, described and illustrated in numerous books. No text of evolution or comparative physiology omits examples based on those mammals. But few people are aware that the nearby minicontinent of New Guinea, with only one ninth of Australia's area, has a related but almost as distinctive and rich mammal fauna. The reason for this unawareness is simple: no comprehensive account of New Guinea's mammals has been available. That deficiency has now been filled by Flannery's book.

The book begins with brief accounts of New Guinea geology, climate, vegetation, zoogeography and extinct mammals, which included cow-sized marsupial herbivores. There follow detailed accounts of all New Guinea's 187 known extant native mammal species, including colour photographs and new field information obtained by the author. Apart from two echidna species, the mammals comprise nearly equal numbers of marsupials, rodents and bats, each group having undergone multiple radiations within New Guinea. Compared to Australia and adjusted air conditioning unit.

This baby-with-bathwater approach, though, falls into the classic trap of the summer holiday genre. Unless the reader is engaged right from the beginning, all these distracting details will only raise suspicions that there really is not much to write about after all. TV dinners that look so colourful tend to be, in the event, profoundly unsatiating, and the shopping trip was, after all, just a shopping trip. Here, as with many sequels, the good bits were all done the first time round, and the rest is dressed up with special effects. Which is a pity, because, with all its faults, Lucy's Child is a cracking good read. Just the sort of thing to while away lazy streetcorner afternoons. But not really serious enough when it's time to put away the skateboard and head back to school.

Henry Gee is on the editorial staff of Nature.

southeast Asia, New Guinea is notably rich in frugivorous bats, aquatic insectivores, and small arboreal folivores, and notably deficient in carnivores (only five species, none weighing over $2 \mathrm{~kg}$ ). The differences from Australia may reflect New Guinea's smaller size, tropical location, much wetter climate and glaciercapped mountains up to 5,000 metres high. The differences from Asia reflect the inability of flightless placentals other than rodents to reach New Guinea, and the resulting radiation of New Guinea mammals to fill niches occupied in Asia by placentals such as primates and squirrels.

Mention of some New Guinea specialities described by Flannery will help convey a sense of his book. Among New Guinea's marsupials are: six species of large kangaroos that live in trees instead of on the ground; phalangers and ringtails, the marsupial equivaient of foliovorous primates; and the possum-like Dactylopsila palpator, strikingly convergent on Madagascar's aye-aye in possessing a very long finger used to pull grubs from rotten logs, and convergent on American skunks in its smell and bold black and white pattern. The murid rodent fauna, one of the world's richest and most highly endemic, includes giant rats weighing up to $1.7 \mathrm{~kg}$, many endemic genera of herbivores and an earless rat confined to cold mountain torrents where it somehow manages to conserve body heat, catch insects and not get swept away. New Guinea's bats include one of the world's largest (a Pteropus flying fox with a 1.5-metre wingspan), the highly specialized and brightly coloured subfamily Nyctimeninae (unusual among Megachiroptera in being insectivores), and the tragic Bulmer's fruit bat (formerly believed extinct for 9,000 years, rediscovered alive in abundance in 1975, and re-exterminated by hunters two years later).

Although Flannery's book will be indis- pensable to vertebrate biologists studying the Australian region, it will find a much wider audience among evolutionary biologists, ecologists, anatomists, physiologists and sociobiologists, for whom this previously inaccessible fauna extends our knowledge of the limits of mammalian adaptation.

New Guinea's endemic birds are as remarkable as its mammals and include birds of paradise, bowerbirds, moundbuilders and a marsupial-like radiation of songbirds. Unlike the case for New Guinea's mammals, its birds are often cited in general biology texts and have been well served by two good modern books, the field guide by B. Beehler et al. (Birds of New Guinea: Princeton University Press; 1986) and the out-of-print handbook by A.L. Rand and E.T. Gilliard (Handbook of New Guinea Birds: Weidenfeld and Nicolson; 1967). Coates' two-volume treatment, of which volume 2 has just been published, nevertheless makes important new contributions. By focusing on the nation of Papua New Guinea, it includes the birds of the Bismarck Archipelago east of New Guinea, for which no modern account has previously been available. It also gathers together for the first time in book form extensive information on the behaviour of all New Guinea bird species.

But for biologists in general the most notable feature of Coates' volumes is the huge collection of colour photographs, which to my prejudiced eye includes some of the most stunning and instructive pictures of animals ever published. Especially valuable are Coates' photos of displaying birds of paradise and bowerbirds, which have been coming to the fore in recent discussions of sexual selection. Most biologists are now aware that the former have the most elaborate sexual display plumage among birds, and that the courtship bowers of the latter are the most elaborately decorated structures erected by any animals except humans. Yet the widely cited verbal descriptions are no match for these revealing photos, which will make concrete for sociobiologists the behaviours whose costs and benefits they now debate. At the risk of singling out five of Coates' photos for special mention, I suggest readers turn first to the masochistic display of Archbold's bowerbird; the belly of the twelve-wired bird of paradise - like a bright yellow light bulb carried below the bird in flight; the fluorescent blue tail wires of the magnificent bird of paradise perched over the display court that it has cleared; and the emperor and blue birds of paradise spreading their plumes while hanging upside-down from a branch.

Jared Diamond is in the Department of Physiology, University of California Medical School, Los Angeles, California 90024, USA. 